\title{
A FRAMEWORK FOR ASSESSING THE SOCIAL AND ECONOMIC IMPACT OF SUSTAINABLE INVESTMENTS
}

\author{
Minna Räikkönen ${ }^{1}$, Susanna Kunttu ${ }^{1}$, Teuvo Uusitalo ${ }^{1}$, Josu Takala ${ }^{2}$, Shah Rukh Shakeel ${ }^{2}$, \\ Sara Tilabi ${ }^{2}$, Teppo Forss ${ }^{3}$, Juha Koivunen ${ }^{4}$ \\ 1 VTT Technical Research Centre of Finland Ltd., Finland \\ ${ }^{2}$ University of Vaasa, Finland \\ 3 TVT Asunnot Ltd., Finland \\ ${ }^{4}$ Humming World Ltd., Finland \\ Corresponding author: \\ Minna Räikkönen \\ VTT Technical Research Centre of Finland Ltd. \\ P.O. Box 1300, FI-33101 Tampere, Finland \\ phone: (+358) 405917590 \\ e-mail: minna.raikkonen@vtt.fi
}

Received: 2 June 2016 Accepted: 3 July 2016

\begin{abstract}
Investments towards sustainable development are vital for the future and they must be carefully planned to deliver immediate and long-term benefits. Hence, the ability to communicate the forms of impact of sustainable investments to local societies, people, investors and other stakeholders can provide a competitive advantage. However, the assessments are often under pressure to demonstrate short-term effects rather than emphasise the long-term impact. In addition, indirect and intangible forms of impacts should not be measured solely in economic terms. This paper proposes an assessment framework to support the integrated economic and social impact assessment of sustainable investments aimed at improving physical and socio-economic wellbeing. The framework is demonstrated in two case studies: new construction and renovation investments in affordable housing and social impact investment in sustainable development. The investments in the case studies are evaluated, selected and prioritized not only in terms of money but also with regard to sustainability, social acceptability and their overall impact on society, as a whole. The results indicate that a systematic integrated assessment of monetary and non-monetary factors can be successfully combined with the sustainable development decisions.
\end{abstract}

KEYWORDS

investment, impact, sustainable development, decision-making, assessment, affordable housing.

\section{Introduction}

Sustainability is often perceived from a limited value creation standpoint. The focus has been on either an economic, compliance, regulation or legislation perspective. There is a need for a more holistic view of sustainability that integrates economic, social and environmental goals. From a network perspective, the scope of value needs to go beyond customers, immediate partners and shareholders to consider relationships, exchanges and interactions. Value can be defined as the set of benefits derived by a stakeholder from an exchange. This implies the need for improved understanding of stakeholder value, and the need to seek opportunities for alignment and exchanges between stakeholders $[1,2]$.

The development of a common value system in a network context is important in order to support the sustainability of collaborative behavior [3]. Different value systems of network partners can lead to different perceptions of benefits and noncollaborative behaviors. In order to overcome this, mechanisms to promote transparency and alignment of value systems could be introduced at the level of governance [4]. A value network generates value through complex dynamic exchanges between enterprises, customers, suppliers, partners, stakeholders and the community. These networks engage in trans- 
actions around goods, services and revenue. In addition, knowledge value and intangible value need to be taken into account [5]. The interdependency between social and business results provides companies opportunities for innovation, growth and social impact at scale [6].

Lately, there has been rising interest and activity in impact investment, which are "investments made into companies, organizations and funds with the intention of generating social and environmental impact alongside a financial return" [7]. The ability to measure and demonstrate the impact of these investments has become increasingly important [8]. Consequently, decision makers are pressured to find new ways to increase awareness of the overall impact of sustainable investments. Frameworks that effectively enable measuring and linking social progress to business success have yet to appear [6].

To support reliable, cost-effective, efficient, and transparent investment decisions, different investment appraisal methods can be applied. A considerable amount of research is done in this area and the general features of these methods are well known [9-12]. Additionally, a variety of methodological approaches to address key aspects of sustainable development can be used. These are based, for example, on multi-criteria analysis (MCA), cost-benefit analysis (CBA), environmental impact assessment (EIA), strategic environmental assessment (SEA), policy assessment, social impact assessment (SIA), and sustainability assessment [13-15]. Each method can be applied depending on the stage and the desired depth of the assessment, and the specific impacts to be examined.

The main motive for this paper is derived from the fact that practical solutions that support decision-makers in the combined assessment of economic and social impact of sustainable investments are still lacking. Furthermore, we argue that many analytical and normative models to aid investment decision-making are often too theoretic and complicated to be used in a practical context.

\section{Research objective and methods}

The objective of this paper is to establish an assessment framework to support the integrated economic and social impact assessment of sustainable investments, addressing how to ensure that resources are efficiently and appropriately allocated to specific activities in order to produce desirable outcome. The underlying research question of this paper is: how to consider both social and economic aspects when assessing impacts of investments aimed at enhancing sustainable development? The two more specific objectives of the paper are:

- to examine different methods and techniques aimed at evaluating the impact of sustainable investments, and

- to propose a practical framework for combining the economic and social aspects of assessment of investments.

The paper is based on research carried out in the research project Towards risk-conscious investment decision-making and value creation partly funded by Tekes, the Finnish Funding Agency for Innovation, via the "New value creation" fund. The project responds to the growing need to enhance the sustainable competitiveness of value networks. It aims to advance companies' ability to create value and to provide decision models and tools to evaluate investments and to assess uncertainty and risk.

The main research methodology is constructive research. A content analysis was used to examine and compare the past and present methods of investment appraisal and impact assessment and to discuss the different aspects of investment decision-making in this context. The actual framework development is based on problem solving and solution building. The framework is demonstrated in two case studies: new construction and renovation investments in affordable housing, and impact investment in sustainable development.

\section{Demonstrating the value of combining economic and social assessment}

Investment decisions are usually taken in a complex and turbulent operating environment where decision-makers are typically confronted with multiple needs, requirements and values. To make sound and justifiable decisions, the investments should be evaluated, selected and prioritized not only in terms of money but also with regard to sustainability, social acceptability and their overall impact on society as a whole. Moreover, every sustainable investment is associated with some key stakeholders that are part of the decision-making process and have a major influence on the outcome. These stakeholders, e.g., public organizations, local, regional and state authorities, private companies and citizens, represent different levels of decision-making and constitutional power in society $[16,17]$.

Figure 1 describes the conceptual assessment framework that was developed and used in the project. The assessment framework takes into account different factors faced by stakeholders affected by sustainable investments. The framework fol- 
lows the premise that decisions shall be taken following the assessment of individual investments according to framework conditions set out by decision parameters such as previous decisions, existing agreements, budget restrictions, uncertainty and social needs, thereby combining the concepts of value, cost and benefit.

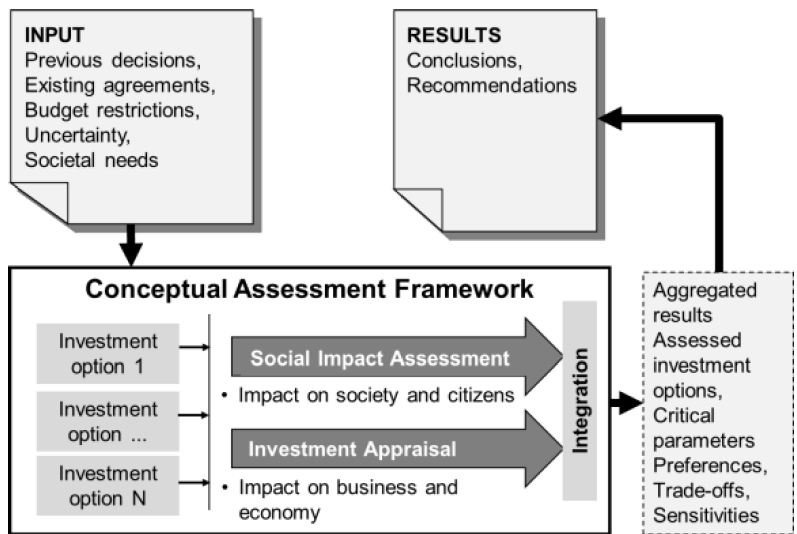

Fig. 1. Conceptual assessment framework.

The assessment framework is based on two modules of analytical tools as depicted in Fig. 1:

Social impact assessment: Evaluating all criteria influencing the decision that cannot be expressed in quantitative terms.

Economic assessment: Comparing those impacts of the investment(s) that can be expressed in monetary terms.

There will be a certain dependency between the individual modules, relying on input from others. For example, for the calculation of monetary values, the data on the various forms of social impact is needed. The results thereof will be consolidated and integrated to form a comprehensive analysis in order to support strategic decision-making. Next, the application of the conceptual assessment framework is discussed through the case studies - affordable housing and social impact investment.

Case 1: New construction and renovation investments in affordable housing

The case company TVT Asunnot Ltd. is a real estate company owned by the city of Turku in Finland. The company is a public non-profit corporation that offers affordable rental housing for people in different life situations aiming to maintain and promote wellbeing of individual citizens and society. TVT Asunnot Ltd. owns a wide variety of residential options in blocks of flats, terraced houses and small private homes throughout Turku. The company owns almost 11000 homes with market asset value of over 1 billion $€$. The company has yearly turnover of $75 \mathrm{M} €$, administration, maintenance and repairs add up to $48 \mathrm{M} €$ and finance costs are $23 \mathrm{M} €$. There is a government-imposed maximum limit on profit. Excess profit is used to lower the rent level prices and for new investments $[18,19]$.

The framework in this case study is concerned with assessing new construction and renovation investments on a strategic, i.e., medium- to long-term horizon. The decision making is characterized by several stakeholders: TVT Asunnot Ltd., the City of Turku, national and regional authorities and agencies and tenants. Thus, the investment decisions are embedded in a complex web of interdependences that has to be taken into account. The potential impact of investment decisions have to be made transparent and be analyzed from different viewpoints.

The case company has two main economic restrictions that have an effect on investments. It is a nonprofit corporation, but it needs to cover expenses. Public funding is used in investment financing, when loan terms are more favorable than in an open financial market. The company is required to limit the rent to a level that is about $10 \%$ lower than in the same kind of tenements in free markets.

The assessment process in this case comprises five steps (see Fig. 2). The process can be applied both to determine the economic profitability of, and assess the social aspects of, alternative investments in renovation or new houses and to compare them with each other. As a result of the assessment, different types of result indicators that combine economic and social viewpoints are illustrated. The key issue in considering the usefulness of the results is reliability, which in this case is mainly dependent on the availability of monetary and quantitative values for various forms of impact, costs and benefits and the success in scoping and defining non-monetary forms of impact. Sensitivity analysis is used to reveal how the ranking of investments can change if values deviate from original estimates.

\begin{tabular}{|c|c|c|c|c|}
\hline $\begin{array}{l}\text { Establishing } \\
\text { assessment }\end{array}$ & $\begin{array}{l}\text { Economic } \\
\text { assessment }\end{array}$ & $\begin{array}{l}\text { Social impact } \\
\text { assessment }\end{array}$ & Results & $\begin{array}{l}\text { Sensitivity } \\
\text { analysis }\end{array}$ \\
\hline $\begin{array}{l}\text { - Definition of } \\
\text { investment } \\
\text { options }\end{array}$ & $\begin{array}{l}\text { - Basic } \\
\text { calculation } \\
\text { parameters, } \\
\text { such as } \\
\text { discounting } \\
\text { rate etc. } \\
\text { - Investment } \\
\text { costs } \\
\text { - Annual costs } \\
\text { - Annual } \\
\text { incomes }\end{array}$ & $\begin{array}{l}\text { - Value to } \\
\text { owner } \\
\text { - Socio- } \\
\text { economic } \\
\text { value } \\
\text { - Regional } \\
\text { economic } \\
\text { value } \\
\text { - Value to } \\
\text { tenants } \\
\text { - Ecological } \\
\text { value }\end{array}$ & $\begin{array}{l}\text { - Figures and } \\
\text { tables } \\
\text { presenting } \\
\text { results in a } \\
\text { form useful to } \\
\text { compare } \\
\text { alternatives }\end{array}$ & $\begin{array}{l}\text { - Analysis of } \\
\text { how sensitive } \\
\text { results are } \\
\text { for changes } \\
\text { in evaluation } \\
\text { and } \\
\text { assessment } \\
\text { parameters }\end{array}$ \\
\hline
\end{tabular}

Fig. 2. Economic and social impact assessment steps in the case study of affordable housing. 


\section{Economic assessment}

Social housing projects are typically evaluated by traditional investment appraisal methods such as cost benefit analysis (CBA) [20]. Economic assessment as an only method will provide too narrow perspective for affordable housing investment decisions. It is, however, necessary in order to balance costs and incomes. In this framework the economic assessment aims to assess whether the intended rent level can be achieved by the proposed investment or which of the proposed investments is the most suitable from a profitability standpoint.

In order to estimate the profitability of an investment, it is necessary to first define investment costs as well as annual costs and income. Investment costs can typically be obtained from offers and other documents. Expected annual costs in the real estate business can be estimated rather accurately utilizing data and experiences from previous investment projects on tenement houses. Typical forms of company's income are tenants' rent and other living costs (parking, use of laundry, etc.). Water and electricity payments are also collected from tenants but those are used to cover consumption based water and electricity invoices. Money required to cover expenses can be calculated based on investment costs and annual costs. Basic calculation parameters that are used in the assessment are the discount rate, inflation of expenses, inflation of rent and the expected lifetime of the building.

Results of economic assessment provide the information on which investment options are the most attractive from an economic point of view. The main indicators that are calculated are the rent per square meter required to cover costs and the payback time.

Uncertainty is inherently related to all decisionmaking situations. The simplest form of the sensitivity analysis is what-if analysis. The main source of uncertainty in this case is the utilization rate of homes. A low utilization rate decreases income while costs remain fixed, which causes pressure to raise rents. The sensitivity analysis creates information on what is the lowest utilization rate still providing an acceptable rent level and covering costs.

\section{Social impact assessment}

The social impact assessment in this case study is made by applying multi-criteria decision-making techniques. The method used to assess the nonmonetary forms of impact of affordable housing is derived from the work of Keeney \& Raiffa [11] who presented the multi-attribute utility theory (MAUT). The multi-attribute utility theory provides a tool to aggregate different aspects, which can be tangible and/or intangible, into one index which can enhance the comparison of investments from a social point of view. Weights needed in calculations are defined by an analytical hierarchy process (AHP) developed by Saaty [21]. The underlying objective is to establish relative weights for the main criteria and factors by means of pairwise comparison. Generally, the more critical a factor is, the more weight it should be given. These methods were chosen since they provide a flexible and easily understood way of analyzing complicated problems and allow consideration of subjective and objective factors in the decision-making process and can handle conflicting factors.

In the case study, the hierarchy for categorizing forms of social impacts of new construction and renovation investments was developed (Fig. 3). It was created by analyzing and combining the knowledge and opinions of experts in affordable housing in TVT Asunnot Ltd. and the results of literature review conducted by the researchers. In addition to the top level, "New construction and renovation investments in affordable housing", the structure includes levels of value categories (value to owner, socio-economic value, regional economic value, value to tenants and ecological value), forms of impacts and alternative investment options (Fig. 3).

The structure described in Fig. 3 will be further tested and applied by assessing the case company's current investment and investment proposals. The weighting of value categories and evaluation of various forms of impact will be made during the assessment process by using expert judgment. Each value category is compared in relation to the others and the priorities complied in a pairwise comparison matrix. After that the impacts are ranked and evaluated. In order to increase the objectivity of the evaluation, the impact scoring is determined based on a fixed scoring system. The scales, i.e., the scores for different forms of impact are mainly modelled on a "very high (5)", "high (4)", "medium (3)", "low (2)" and "very low (1)" scale. For some forms of impact, different scales are introduced to ensure better transparency of the results. In addition, some forms of impact are not evaluated and instead more qualitative information on the particular form of impact is given.

By multiplying the weights and the impact scores, the profile for different investment options can be illustrated. The weighted score for individual investment can be calculated and different options can be ranked. After the ranking of evaluated investments is made, the decision-makers have preliminarily determined the order of superiority of alternative investments. 


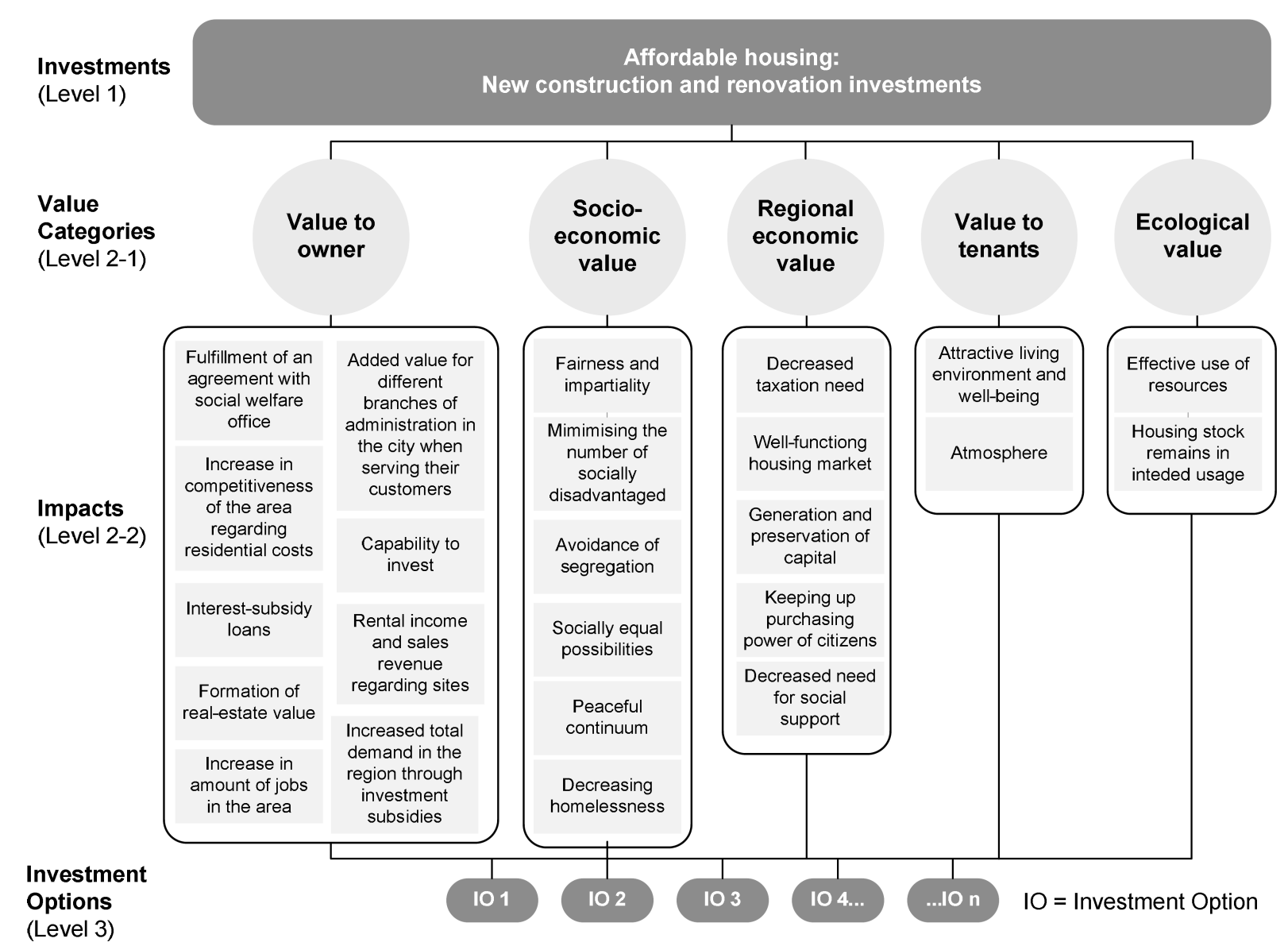

Fig. 3. The proposed impact structure for new construction and renovation investments in affordable housing.

Case 2: Social impact investment in sustainable development

Humming World is a Finnish start-up company that aims to deliver high-impact projects in developing countries through partnerships and co-operative actions. The platform Humming World is a business solution and a crowdfunding website that will be developed to connect people, and to solve the challenges within project financing, project development and global market linkages [23]. The research with Humming World Ltd. in the project focuses on the development of the impact assessment framework for social impact investments. The developed framework will later be incorporated into the company's website. The ability to communicate the impact of investments to local societies and people as well as other investors will provide a competitive advantage.

The method that inspired and supported the development in this case study is the impact value chain. The process of the impact value chain traditionally starts with input-level data and progresses to activity, output, outcome, and impact-level data [24-26]:
- Inputs: all resources, whether capital or human, invested in the activities of the organization.

- Activities: the concrete actions, tasks and work carried out by the organization to create its outputs and outcomes and achieve its objectives.

- Outputs: the tangible products and services that result from the organization's activities.

- Outcomes: the changes, benefits, learnings or other effects (both long and short term) that result from the organisation's activities.

- Social impact: the attribution of an organisation's activities to broader and longer-term outcomes.

Ideally, impact should concern the long-term social and environmental benefits that an investment generates [26, 27].

Humming World's Thompukandam Village Destination (TVD) program laid the groundwork for the framework development. The TVD program is introduced and established through three development areas: sustainable tourism development, livelihood projects to foster and facilitate small-scale industrial livelihood opportunities, and solid waste management development. The aim is to bring together 
local community and its people, socially conscious consumers and local and international stakeholders from financiers and investors to business partners. Through the TVD program, the community and its people will rise economically and technically to a higher level.

The assessment is intended to cover the widest possible range of impact that may arise from the TVD program. An important step in the research was to gain an in-depth understanding of economic, environmental and social impacts of the TVD program. Until now the developed structure includes three major impact areas: employment, training and education, citizenship and community and conservation of natural environment. In order for the impact structure to become a usable tool for data collection, a suite of impact indicators needed to be developed under each of impact areas. In addition to the impacts, Table 1 gives an overview of the indicators which were identified to be the most relevant for the
TVD program. All the identified impacts and indicators represent a combination of the insights dealing with the knowledge and future prospects of the company's experts who participated in the research, the results of the literature review and the researchers' own experience.

The impact structure and identified indicators will be used as a basis for the financial and social impact assessment. As the TVD program is now in the launch phase, the data from previous projects should be used and it needs to be completed with the data gathered from experts and citizens. Depending on the data available, collection methods can vary from content reviews and interviews to statistics. It should also be taken into account that the quality and reliability of assessment results are correlated to the quality of the employed data [29]. Therefore, high data quality needs to be emphasized when planning data gathering in the TVD program.

Table 1

The proposed impacts and impact indicators for the TVD program (based on [28]).

\begin{tabular}{|c|c|c|}
\hline Ipacts a & & \\
\hline $\begin{array}{l}\text { Improved quality of education } \\
\text { - } \quad \text { School scores on numeracy, literacy, IT, problem- } \\
\text { solving tests } \\
\text { - National literacy rates } \\
\text { - Percentage of population achieving higher education } \\
\text { degrees } \\
\text { - National school absence rate and number of permanent } \\
\text { and temporary exclusions } \\
\text { Improved quality and availability of training that } \\
\text { fits with the needs of employers } \\
-\quad \text { Number of training opportunities available } \\
\text { - Breadth of training opportunities available (e.g. } \\
\text { vocational instruction and interviewing } \\
\text { skills, job-related technical skills, and emotional } \\
\text { intelligence and soft skills) } \\
\text { Number of apprenticeships and internships that convert } \\
\text { into full-time jobs } \\
\text { Number of job vacancies because of skills shortages } \\
\text { - Unemployment and long-term unemployment rates } \\
\text { - Proportion of people who are accessing better support } \\
\text { programmes to find work } \\
\text { Increase in the local job supply } \\
-\quad \text { Number of jobs created } \\
-\quad \text { Number of jobs sustained } \\
\text { - Unemployment and long-term unemployment rates } \\
\text { Increase in the number of small and local businesses } \\
-\quad \text { Number of companies/start-ups created } \\
-\quad \text { Number of small and local businesses facilitated (e.g. } \\
\text { through provision of training, support) } \\
\text { Improved government investment, expenditure and } \\
\text { procurement } \\
-\quad \text { Government investment in employment, training and } \\
\text { education } \\
\text { Government expenditure on improving access to and } \\
\text { quality of education } \\
\text { Funding for public programmes/schemes that promote } \\
\text { employability } \\
\text { Foreign investment in sustainable infrastructure and } \\
\text { business development }\end{array}$ & $\begin{array}{l}\text { Local economic growth } \\
-\quad \text { Local spending } \\
-\quad \text { Local currencies } \\
\text { Cleaner communities } \\
\text { Local investment } \\
-\quad \text { Levels of littering } \\
-\quad \text { Rorking waste management system } \\
-\quad \text { Barbed wire and other hazards removed from the } \\
\text { environment } \\
\text { Increased engagement with the community and } \\
\text { community groups } \\
-\quad \text { Availability of opportunities to participate in and } \\
\quad \text { contribute to the local community } \\
-\quad \text { Levels of participation in community activities } \\
-\quad \text { Levels of membership of community groups } \\
\text { Donations to community charities and groups } \\
\text { (collective trademark makes this possible) } \\
\text { Number of community owned and managed assets } \\
\text { Increased sense of belonging in the community } \\
-\quad \text { Number of people who report feeling a sense of } \\
\quad \text { belonging in the community } \\
\text { Level of recognition in society of the positive role } \\
\text { that all groups can play in communities } \\
\text { Conservation of natural spaces, natural heritage } \\
\text { and biodiversity } \\
-\quad \text { Area of natural space or heritage restored or created } \\
-\quad \text { Air quality measures (relating to diminished } \\
\text { environmental risk) } \\
\text { - Number of visitors to conserved spaces } \\
-\quad \text { Service fees related to entry to national parks } \\
\text { (Ampara region, through services e.g. by hiring a } \\
\text { guide) }\end{array}$ & $\begin{array}{l}\text { Improvements in general waste and recycling } \\
\text { - Reduced waste (e.g. percent recycled, percent re- } \\
\text { used, percent donated, amount going to landfill) } \\
\text { Consumption of materials (e.g. amount of materials } \\
\text { used, proportion of input materials } \\
\text { from recycled/re-used sources) } \\
\text { Increased organic farming practices } \\
\text { Reduction in harmful waste and pollution } \\
\text { - Reductions in: } \\
\quad \text { toxic and chemical emissions to water, } \\
\quad \text { soil (type and volume) } \\
\quad \text { incidence of hazardous waste, spills } \\
\text { Volume of harmful waste responsibly disposed of } \\
\text { Remediation of environmental damage from } \\
\text { pollution } \\
\text { Improved public awareness } \\
\text { General availability of accurate and comprehensible } \\
\text { information (collaboration with the local university) } \\
\text { Level of media exposure associated with } \\
\text { conservation of the natural environment (e.g. } \\
\text { number of articles published on the subject in } \\
\text { mainstream media; exposure on tv, radio; } \\
\text { internet traffic) } \\
\text { Level of public awareness about the causes and } \\
\text { consequences of the problem } \\
\text { Public events, rallying, campaigning } \\
\text { Public donations to related charities } \\
\text { Number of school and professional visits to } \\
\text { Thompukandam destination (to learn from a best } \\
\text { practice case) } \\
\text { Number of educational programs run } \\
\text { Improved public engagement } \\
\text { Institutional and organisational engagement with } \\
\text { stakeholders over issues related to sustainability and } \\
\text { the conservation of the natural environment } \\
\text { Public volunteering on projects and initiatives } \\
\text { Public levels of engagement with sustainable } \\
\text { behaviours (e.g. energy saving, recycling, water } \\
\text { usage, transport) }\end{array}$ \\
\hline
\end{tabular}




\section{Conclusions}

This paper proposes a practical assessment framework to support the integrated economic and social impact assessment of sustainable investments aimed at improving the physical and socio-economic wellbeing. The framework was developed in close cooperation between researchers and case companies who brought their domain competence to the development work. Structured and systematic assessment process enhances the transparency of investment decision-making and increase the capability to handle-multifaceted situations with sometimes conflicting views of the parties involved in the decisionmaking.

As with any empirical research, the limitations of the proposed framework must be taken into account. For example, it may not cover all the important aspects of linking economic and social factors. The availability and reliability of data can also be considered as a major challenge when conducting an assessment. Moreover, special considerations must be made regarding the expert judgement. The weights and scores for various forms of impact in the social impact assessment cannot typically be supported by empirical analysis as the data simply does not exist. Thus the credibility of the assessment is dependent on the decision-makers and stakeholders abilities to provide reliable judgments. However, by performing a sensitivity analysis, the impact of changes in different assessment parameters can be analyzed.

The framework will be further evaluated and tested in the case studies and developed into a software application to guide the user through the assessment process.

The research is part of the project "Towards riskconscious investment decision making and value creation" in the call "New Value Creation" of Tekes, the Finnish Funding Agency for Innovation. The project is jointly funded by Tekes, participating companies and research parties. The authors want to thank TVT Asunnot Ltd. and Humming World Ltd. for providing the case studies and for their assistance in data acquisition as well as for insightful discussions and comments during the research.

\section{References}

[1] Evans S., Rana P., Short S., D2.1 - Stateof-practice in business modelling and valuenetworks, emphasising potential future models that could deliver sustainable value, 2012, available: http://www.sustainvalue.eu/publications/D2_1_Fi-
nal_Rev1_0_web.pdf. Last accessed 21th June 2016.

[2] Porter M.E., Kramer M.R., Creating shared value, Harv. Bus. Rev., 89, 2-17, 2011.

[3] Camarinha-Matos L.M., Macedo P., A conceptual model of value systems in collaborative networks, Journal of Intelligent Manufacturing, 21, 3, 287-299, 2010 .

[4] Abreu A., Camarinha-Matos L.M., On the role of value systems to promote the sustainability of collaborative networks, International Journal of Production Research, 46, 5, 1207-1229, 2008.

[5] Allee V., Reconfiguring the value network, Journal of Business Strategy, 21, 4, 36-39, 2000.

[6] Porter M.E., Hills G., Pfitzer M., Patscheke S., Hawkins E., Measuring shared value: how to unlock value by linking social and business results, FSG, 2012 .

[7] What You Need to Know About Impact Investing | The GIIN https://thegiin.org/impactinvesting/need-to-know/, last accessed 21 June 2016.

[8] Social Impact Investment Taskforce, Measuring Impact, Subject paper of the Impact Measurement Working Group, 2014.

[9] Götze U., Northcott D., Schuster P., Investment appraisal: methods and models, Springer-Verlag: Berlin-Heidelberg, 2008.

[10] Pike R., Neale B., Corporate finance and investment: decisions and strategies, 4th ed. Prentice Hall: Harlow, 2003.

[11] Keeney L., Raiffa H., Decisions with multiple objectives: preferences and value trade-offs, Cambridge University Press, 1993.

[12] IEC 60300-3-3 ed2.0. Dependability management Part 3-3: Application guide - Life cycle costing, 2004.

[13] Boardman A.E., Greenberg D.H., Vining A.R., Weimer D.L., Cost-benefit analysis: concepts and practice, 3rd ed. Prentice Hall, 2006.

[14] Fuguitt D., Wilcox S.J., Cost-benefit analysis for public decision makers, Quorum Books; Westport, CT, 1999.

[15] Bond A., Pope, J., The state of the art of impact assessment in 2012, Impact Assessment and Project Appraisal, 30, 1, 1-4, 2012.

[16] Räikkönen M., Välisalo T., Shylina D., Tilabi S., Supporting asset management decision-making - 
new value creation perspective, 10th World Congress on Engineering Asset Management, WCEAM 2015, 28-30 September 2015, Tampere, Finland Proceedings of the 10th World Congress on Engineering Asset Management (WCEAM 2015) Lecture Notes in Mechanical Engineering, Springer, 479-486, 2016.

[17] Räikkönen M., Pilli-Sihvola K., Kunttu S., Yliaho J., Jähi M., Zuccaro G., Del Cogliano D., Assessing economic impacts of crises - a decision-support approach to long-term strategic planning, Proceedings of the IX International Conference on Risk Analysis and Hazard Mitigation, C.A. Brebbia [Ed.], WIT Press (Wessex Institute of Technology), pp. 229241, Risk Analysis 2014, New Forest, UK, 4-6 June 2014.

[18] Forss T.,Improving operational performance within social housing, dissertation, Acta Wasaensia 280, 2013, ISBN 978-952-476-449-0.

[19] TVT Asunnot Ltd., http://tvt.fi/english/.

[20] Higham A.P., Fortune C., Boothman J.C., Sustainability and investment appraisal for housing regeneration projects, Structural Survey, 34, 2, 150-167, 2016.

[21] Saaty T.L., The analytic hierarchy process, McGraw-Hill, New York, 1980.
[22] Kortelainen H., Räikkönen M., Komonen K., Corporate asset management - a semi-quantitative business-driven approach to support evaluation of improvement options, Int. J. Strategic Engineering Asset Management, 2, 2, 208-222, 2015.

[23] Humming World Ltd., http://hummingworld.com/,

[24] W.K. Kellogg Foundation, Logic Model Development Guide, 2014.

[25] Clark C., Rosenzweig W., Long D., Olsen S., Double bottom line project report: assessing social impact in double bottom line ventures, Methods Catalog. University of California, Berkeley, 2004.

[26] Hehenberger L., Harling A.-M., Scholten P., A practical guide to measuring and managing impact, European Venture Philanthropy Association, 2013.

[27] Social impact Investment taskforce, Measuring impact. Subject paper of the Impact Measurement Working Group, 2014.

[28] Outcomes matrix, http://www.goodfinance.org.uk/ impact-matrix.

[29] Beschen D., Day R., Gretchen J., Rohm H., The performance-based management - collecting data to assess performance, volume four, PerformanceBased Management Special Interest Group (PBM SIG), 2001. 